\title{
Preface to Original Edition
}

Theories of local government developed when the world was still composed of decentralized, agrarian societies. Yet advanced industrialization and the urbanization of society have not brought an end to local government; it has continued to survive, along with various other clements of the decentralized early modern state. Its focus, however, has had to adapt, since conditions have greatly changed. Rapid economic development has strengthened the interdependence of central and local governments, and today the central-local relationship has become close in every developed state. In addition, waves of influence from the international sphere have swept across regional society. And the present information age is beginning to raise a number of questionsfor example, what kinds of principles should govern the interface between the computers of central ministries and of local governments? In the future, as the populations of industrial societies age, the welfare functions of local governments will expand and the frequency of intergovernmental cooperation will increase.

In times like ours, when central-local relations are intense, is the autonomy of local governments still significant? Is it even possible? The answer to both questions is "yes." But what does that mean in practical terms?

This book analyzes forty years of local government and central-local relations in postwar Japan. The first chapter provides a comparative perspective, touching on the broad realities and principles of central-local relations in advanced industrialized states. It also introduces Japanese 
debates over local government through the theories of two scholars of public administration (Nagahama Masatoshi and Tsuji Kiyoaki). Chapter 2 describes how these two theories have become orthodox and discusses their content. These theories, which suggest an absence of local autonomy, have dominated debate for a long time, although recently contradictory arguments have been presented in a number of places. A third, newer theory argues that the bottom-up political competition of local government in fact determines central-local relations. Chapter 3 attempts to explain this theory, based on an analysis of interviews with prefectural governors, since the popular election of governors was a major factor in the great postwar reform that transformed the role of the prefectures and encouraged local autonomy. Chapter 4 continues this effort, attempting to demonstrate the adequacy of the new model at the municipal level. In Chapter 5 I reinvestigate the concept of local government overall using the new perspective, and in Chapter 6 I provide an understanding of the nature of Japanese local government. As this book relates, chibo jichi, the common Japanese term for local government, connotes not just local autonomy but also "self-management" or "self-control." This kind of autonomy has been or can be achieved to a great extent even in highly centralized present-day Japan. But to observe and analyze it we must go beyond studies of control strategies of the center over local governments, lower the focus of our discussion to the municipal level, and analyze the process of local government operation. This book is based on a study of the government of the city of Kyoto (Miyake and Muramatsu 198I), but additional studies of government processes on the local level are needed to provide a comprehensive and conclusive analysis. I hope in the future to analyze further the structure and processes of local government.

It has taken a long time to write this book, and it has built upon the research of many other scholars, who deserve my deepest thanks. I especially enjoyed the intellectual stimulation of Nagahama Masatoshi's Chihō jichi (1952), which fostered my interest in local government, and the penetrating analysis of Japan's political administration by Tsuji Kiyoaki, whose views have served as the paradigm of orthodoxy in Japanese political science. Katō Kazuaki deepened my understanding of the present situation in local government. When I was in the midst of conceptualizing this book, Terry MacDougall and Ōmori Wataru organized a conference, where I was able to exchange ideas with scholars of central-local government relations in other countries. I was heartened to learn that a number of scholars overseas were advancing theories in the 
same direction as I. I especially profited from participating in conferences in Turin, Bellagio, and New York with Robert Putnam, Bruno Dente, Sidney Tarrow, Douglas Ashford, Michael Aiken, Peter Lang, and Richard Samuels. As for the data and research materials treated here, I would like to acknowledge with thanks the Gyōsei Kanri Kenkyū Sentā (1985) study and my colleagues there: Ōmori Wataru, Nakamura Akira, Takeshita Yuzuru, Kitahara Tetsuya, and Koike Osamu. I am also grateful to Yonehara Junshichirō for allowing me to use his data in chapter s. I commissioned the Chūō Chōsasha to carry out the survey of governors. Many people lent a hand in preparing the data and manuscript for this book, and I am particularly indebted to Horibe Kiyoko and Kobayashi Yasushi for their help in the final stages.

Lastly, I would like to thank Inoguchi Takashi, who planned and promoted the Contemporary Japanese Politics series and gave me the opportunity to write this volume, and Takenaka Toshihide of the University of Tokyo Press, which published the series. Neither remote nor interfering, Mr. Takenaka took exactly the right stance to lead this book to completion.

This book is dedicated to my daughters, who sent their support to their often absent father. 
